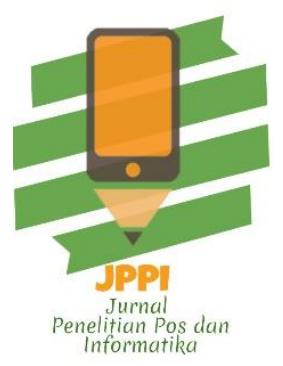

Doi:10.17933/jppi.2019.090101

\title{
QUALITY EVALUATION OF PASURUAN REGENCY OFFICE OF EDUCATION'S WEBSITE USING WEBQUAL 4.0 FRAMEWORK AND IMPORTANCE PERFORMANCE ANALYSIS (IPA)
}

\author{
EVALUASI KUALITAS WEBSITE DINAS PENDIDIKAN \\ KABUPATEN PASURUAN MENGGUNAKAN KERANGKA KERJA \\ WEBQUAL 4.0 DAN IMPORTANCE PERFORMANCE ANALYSIS \\ (IPA)
}

\author{
Admaja Dwi Herlambang ${ }^{1}$, Rizki Widya Priyangga. ${ }^{2}$, Niken Hendrakusma Wardani ${ }^{3}$ \\ 1,2,3 Faculty of Computer Science, Brawijaya University \\ 'herlambang@ub.ac.id
}

Naskah Diterima: 13 Oktober 2017; Direvisi : 08 Desember 2017; Disetujui : 08 Desember 2017

\begin{abstract}
Abstrak
The purpose of the evaluation is to find out the quality of usability, information quality, and service interaction quality of Pasuruan Regency Office of Education's website. The Sample was 100 respondents from a population of website users, with simple random sampling technique. Data was obtained from dissemination of questionnaires which were then analyzed using descriptive statistics and calculation of Importance Performance Analysis (IPA). The results of the descriptive statistics pointed out that all three variables were included in the high category. The value of variable gap usability was of -0.35, information quality of-0.32, and service quality of interaction of -0.36. Based on these results, it is concluded that the website has not been able to fulfill the ideal quality as expected by users. Indicators that need improvements include website color design for more comfort to the eyes of users, types and sizes of fonts for more readability, background color to provide contrasts to the font color, up to date information, information useful for user, ease of communication with other organizations, and speed of response and comment.
\end{abstract}

Keywords: evaluation, usability, information quality, service interaction quality, website, office of education 


\section{INTRODUCTION}

The Pasuruan Regency Office of Education plays a significant role in assisting schools located in Pasuruan regency in performing regulatory and administrative tasks. Therefore, the Office of Education has been innovating its services by developing a website which serves as a means of information provider and consultation services for public. The website was built to provide information and serve the academic community, particularly those in the fields of elementary, secondary, and higher education. Information provided in the website is related to activities, achievements, and information related to Pasuruan Regency.

Information was gathered from an interview session with the website manager. First, in terms of website appearance, the education office's website has been undergoing changes from year to year, in both its appearance and framework. The current website composition is CodeIgniter framework while website appearance and design refer to the Indonesian Education Ministry's website. Second, in terms of the quality of information provided in the website, it is perceived relevant and has met the needs for current information, schedules of activities, and other information that are useful for public. In operating the website, manager relies on reports from public related to content to be posted in the Pasuruan Regency office of education's website, due to its lacking of human resources to gather information from the field. Currently there have not been any complaints from the public regarding the quality of information provided in the office of education's website. Third, related to the regional regulation which stipulates the evaluation of Education Office's website, the Pasuruan Regency Office of Education claimed to have not been informed, yet they are aware that there is another institution which regulates policies related to information technology and websites, namely the Office of Communications and Informatics. Fourth, website design of Pasuruan Regency Office of Education only refers to the overall website of Education Ministry. According to interviewees, website design of an organization must refer not only to the Education Ministry but also the State Apparatus Ministry. Fifth, the website only provides one line of service for users, namely one telephone line which is listed in the Kontak Kami (Contact Us) menu.

This study is part of the efforts to realize good governance in terms of the implementation of public participation and government responsiveness in fulfilling public aspiration as considerations for future evaluation. Based on this explanation, it is necessary to undertake an assessment of the service quality of Pasuruan Regency Office of Education's website from users' viewpoint. The results of this study are expected to be taken into consideration by related offices for the preparation of the Draft Ministerial Regulation on Government Agencies Portals and Websites. This regulation will stipulate the ideal appearance of government website in order to be able to provide information services that are useful for public as users (MCI, 2018).

The evaluation of website service quality can be processed by using attributes in the WebQual 4.0 method and Importance Performance Analysis (IPA). Evaluation using WebQual 4.0 was conducted because data was gathered directly from users of Pasuruan Regency Office of Education's website so that the information gathered can represent the perception of website users. IPA analysis was used to 
find out which parts need to be improved so that the website can meet user expectations.

In this study, modification on the statements in WebQual 4.0 was made for the original statements in WebQual 4.0 were more related to e-commerce website. In order to ease users in completing the questionnaires, modification on WebQual statements on a number of relevant literatures were made to avoid user confusion on deciding their answer (Diana, 2014).

Importance-Performance Analysis (IPA) is an analysis tool to measure the relationship between consumers' perspective and service or product quality improvement priorities which later known as the quadrant analysis (Latu \& Everett, 2000; Brandt, 2004). According to Martinez in Santoso \& Anwar (2015), IPA has been generally accepted and used in the field of study because of its easy application and it displays analysis results that facilitate proposals for performance improvement.

Appropriateness level analysis is the results of a comparison between the performance scores and importance scores which is used to determine whether the website performance is appropriate with users' interests, where $\mathrm{X}$ is performance level or perception, and $\mathrm{Y}$ is interest level or expectation (Supranto, 2011 in Nasrullah 2015). Suitability level analysis determines the priority scale used in handling the results of quadrant analysis. Criteria for user suitability level evaluation are (a) appropriateness level of more than $100 \%$ which means that performance is more than expectation and users may be declared satisfied; (b) Appropriateness level of equal to $100 \%$ which means users expectation is suitable with the experiences performance and users may be declared satisfied; and (c) Appropriateness level of less than $100 \%$ which means performance is below users' expectation, which means that users are not satisfied.

Gap analysis is used as a measure to find out the quality of the website in terms of gap value between the perceived quality (actual) and desired quality (ideal) (Santoso and Anwar, 2015). In the gap analysis, a good quality is noted in positive values or Qi $($ gap $) \geq 0$. This indicates that the actual quality has met the respondents' desired ideal quality. If the result is Qi $($ gap $)<0$ or the value is negative, it means that the quality has not met the users' desired ideal quality.

IPA analysis maps the indicators of each measured variable into four quadrants (Martilla \& James, 1977; Brandt, 2004). There are two criteria in the Priorities for Improvements quadrant, that are high importance and low performance criteria. Indicators that fall into these criteria are perceived as important factors but are not perceived as satisfactory to the current situation by consumers. In this case, management are expected to pay attention to these factors and allocate adequate resources to improve the performance of these factors. There are two criteria that fall into the Keep Up the Good Work Quadrant, high importance and high performance criteria. Indicators that fall into this quadrant are perceived as factors that support consumers satisfaction so that management must ensure the organization performance to maintain the achievement.

The Lowest Priority Quadrant has the criteria of low importance and low performance. Indicators that fall into this quadrant are perceived to have low level of satisfactory and perceived as less important by consumers. Therefore, management need not to prioritize these factors. The Possible Overkill Quadrant has two criteria, low importance and high performance. Indicator that fall into this quadrant are 
perceived less important so that management may allocate related resources to other factors needing improvement.

\section{METHODOLOGY}

This study uses a quantitative approach. A quantitative study identifies a research problem based on trends in the respective field or the necessity to explain why something happened (Recker, 2013). This study is carried out in several stages, including formulating research problem, literature review, designing the research, selecting evaluation standards, selecting a sample, selecting instruments, data analysis, data interpretation, and recommendations. Based on interviews at the preresearch stage, it is found out that no assessment on Pasuruan Regency Office of Education's website ever made before. The Literature Review contains a systematic description of information on studies conducted earlier which are relevant to this ongoing study, as well as other scientific theories to which this study is referred and which is used in completing this thesis.

The next stage is designing the research appropriate with the researched topic. This study uses WebQual 4.0 framework with 19 indicators as reference in the formulation of questionnaire, with two statements for every indicator. Evaluation standards used us WebQual 4.0 concept which has 3 variables, namely usability with 8 indicators, information quality with 7 indicators, and service interaction quality with 4 indicators.

Size of the population selected for sample of this study is the monthly average number of users of Pasuruan Regency Office of Education's website, that is, 40,650 users. Simple random sampling technique is used in this study, where items are selected randomly and every item in the population has an even chance of being selected in the sample. Sample size is determined by the Slovin Formula at a $10 \%$ margin of error. Sample size acquired is 100 respondents.

Instrument of research in this study is questionnaire comprising detailed questions based on WebQual 4.0 indicators. Measurement scale used in this study is Likert type-scales which uses 5-point response scales starting from strongly disagree to strongly agree for performance, and not at all important to very important for importance. The instrument is an adaptation to Barnes and Vidgen's study on WebQual 4.0 model which was processed by Diana (2014).

Data analysis is carried out after questionnaire data is obtained from respondents. Before the questionnaires are distributed to the entire respondents, face validity and content validity were carried out to assess the validity of instrument. After the instrument validity is assessed, item validity assessment is then carried out. After the item validity on usability variable is conducted, 1 statement was cancelled, leaving 13 valid and reliable statements. For the information quality variable, there are 12 valid and reliable statements, while for service interaction quality variable, there are 8 valid and reliable statements.

\section{RESULTS AND DISCUSSION}

The results of a descriptive analysis on the variables of usability, information quality, and service interaction quality on Pasuruan Regency Office of Education's website in terms of its performance by mean values is described in Table 1. The results of a descriptive analysis on the variables of usability, 
information quality, and service interaction quality on Pasuruan Regency Office of Education's website in terms of importance by mean values is described in Table 2. The results of suitability assessment on the variables of usability, information quality, and service interaction quality can be seen in Table 3, which shows that the average total value of the three variables $<100$.

Table 1. Results of Descriptive Analysis for

\begin{tabular}{ccc}
\multicolumn{3}{c}{ Performance } \\
\hline Variable & Percentage & Information \\
\hline Usability & $69.84 \%$ & High \\
\hline Information Quality & $69.68 \%$ & High \\
\hline $\begin{array}{c}\text { Service Interaction } \\
\text { Quality }\end{array}$ & $70.33 \%$ & High \\
\hline
\end{tabular}

The results of gap assessment of usability, information quality, and service interaction quality show that all variables have negative values as described in Table 4.

Table 2. Results of Descriptive Analysis for Importance

\begin{tabular}{ccc}
\hline Variable & Percentage & Information \\
\hline Usability & $76.80 \%$ & High \\
\hline Information Quality & $76.07 \%$ & High \\
\hline $\begin{array}{c}\text { Service Interaction } \\
\text { Quality }\end{array}$ & $76.60 \%$ & High \\
\hline
\end{tabular}

Table 3. Suitability Analysis

\begin{tabular}{cc}
\hline Variable & $\begin{array}{c}\text { Average total of Suitability } \\
\text { Rate }\end{array}$ \\
\hline Usability & $90.82 \%$ \\
\hline Information Quality & $91.67 \%$ \\
\hline $\begin{array}{c}\text { Service Interaction } \\
\text { Quality }\end{array}$ & $90.58 \%$ \\
\hline
\end{tabular}

Table 4. Gap Analysis

\begin{tabular}{cc}
\hline Variable & $\begin{array}{c}\text { Average total of Gap } \\
\text { Analysis }\end{array}$ \\
\hline Usability & -0.35 \\
\hline Information Quality & -0.32 \\
\hline Service Interaction Quality & -0.36 \\
\hline
\end{tabular}

The results of IPA quadrant analysis on usability variable in Figure 2 show that every indicator of this variable falls into the Priorities for Improvements, Keep Up the Good Work and The Lowest Priority quadrants.

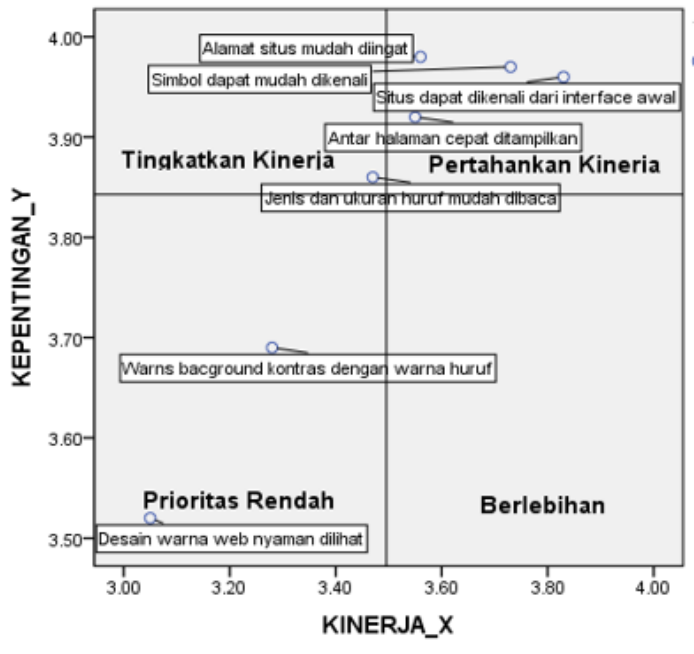

Figure 2. Usability Variable Indicator Map

Indicator which need improvements are indicators that fall into the Priorities for Improvement quadrant, that is, (a) types and sizes of fonts are easy to read and those fall into Lowest Priority quadrant, (a) background color contrasts with font colors; (b) Website color design is comfortable to the eyes. Usability is a quality related with website design, including appearance, ease of use, navigation, and description delivered to users Barnes \& Vidgen (2002) in Tarigan (2008). Indicators of usability include clear and understandable interaction, easy to navigate, attractive appearance, appropriate design, competitive, easy to learn and operate, easy to use, positive experience (Santoso \& Anwar, 2015). Meanwhile, according to Nielsen (2012) to test website usability is to define five component qualities, namely: (1) learnability (How easy is it for users to accomplish basic tasks the first time they encounter a system design); (2) efficiency (Once users have learned the design, how quickly can they perform tasks); (3) memorability (How easy is it for returned users to reestablish proficiency after a period of not using it); (4) errors (How many errors do users make and how easily can they recover from the errors); and (5) satisfaction (How pleasant is it to use the system design). 
Website indicators can be recognized from initial interface after a descriptive statistical calculation phase in the performance aspect. It is found out that the indicator falls into high category. In terms of importance aspect, results also show that the indicator falls into high category. Website indicator can be identified from the initial interface in the IPA quadrant to fall into Keep Up the Good Work quadrant. It means that website managers must be able to maintain such indicator in managing the website. Symbol indicators are easy to recognize after the descriptive statistical calculation phase is carried out in terms of importance, the results show that the indicators fall into high category. From the aspect of performance, it was found that the indicators also fall into the high category. Symbol indicators are easily recognized to fall into the IPA quadrant of Keep up the Good Work, meaning that website managers must be able to maintain these indicators in managing the website.

For the indicators for website color design is comfortable for users eyes, the results of descriptive statistical calculation phase in the aspect of performance show that the indicators fall into the category of fairly high. In terms of importance, the results show that the indicators fall into high category. Website color design indicators in the IPA quadrant fall into the lowest priority quadrant, meaning that the indicators in this quadrant have a low level of satisfactory while at the same time the performance is perceived as less important by users. Indicators that fall into the low priority quadrant are indicators that are perceived fairly suitable and not the main priority for improvement. Website color design that is comfortable for users is related with its appearance. This study recommends that improvement be made on the website's visual by making the website more attractive and familiar. A website can be attractive when it has a high contrast between its text and background or between text and images, different colors should be able to distinguish one object from other another (Suyanto, 2007).

For the indicators of font types and sizes are easy to read, the results of descriptive statistical calculation phase in the aspect of performance show that the indicators fall into in the high category. In terms of importance, the results show that these indicators also fall into the high category. The indicators of font types and sizes are easy to read in the IPA quadrant in the Priorities for Improvements quadrant, meaning that the indicators in this quadrant are perceived as important by users, but Pasuruan Regency Office of Education's website manager has not been able to meet users' expectations so that users experience dissatisfactory and the Pasuruan Regency Office of Education's website manager shall improve the performance of the indicators that fall into the Priorities for Improvement quadrant.

In terms of content delivery to users, the font types and sizes are easy to read. This study recommends that website content writing be improved, to give high contrast between texts and backgrounds and between texts and images, to choose fonts that are easy to read, such as serif and sans-serif fonts. Decorative or cursive typefaces are more difficult to read. These fonts are usually used for titles, given that they are written in large sizes. The sans-serif font is occasionally easier to read than serif when written in lowercase. In addition, a reset on leading and kerning is needed. Leading is the spacing between the baselines of the typeface, while kerning refers to the space between characters. Use standard fonts 
found on all computers or browsers, such as Times New Roman, Helvetica, Arial, and Verdana. If you want another typeface that is unique for decoration, make it a graphic (Suyanto, 2007).

For indicators of background color contrasts to the font colors, the results of descriptive statistical calculation phase in the aspect of performance show that the indicators fall into the fairly high category. In terms of importance, the results show indicators fall into high category. Indicators for background color contrasts font color in the IPA quadrant fall into the low priority quadrant, meaning that the indicators in this quadrant received a low level of satisfaction and its performance is perceived less important by users. Indicators that fall into the low priority quadrant are perceived fairly appropriate and not the main priority for improvement. The contrast of background color with font color is related to website appearance. This study recommends that website visual be improved by making the website attractive and familiar. A website can be more attractive by giving high contrast between text and background or between text and images, different colors should be able to distinguish one object from another. A company website usually has clean colors such as blue, white, and gray (Suyanto, 2007).

The results of descriptive statistical calculation stage in the aspect of performance for the indicators of fast loading pages show that these indicators fall into high category. In terms of importance, the results show that the indicators also fall into the high category. Indicators of pages loading fast displayed in the IPA quadrant in the Keep up The Good Work quadrant, meaning that website managers must be able to maintain these indicators. For the indicators of website address easy to remember, the results of the descriptive statistical calculation stage in the aspect of performance show that these indicators fall into the high category. In terms of importance, the results show that the indicators also fall into the high score category. The indicators for website address is easy to remember fall into the Keep Up The Good Work IPA quadrant, meaning that website managers must be able to maintain these indicators in managing the website.

The results of the analysis of the IPA quadrant on the information quality variable in Figure 3 shows that every indicator on this variable fall into the keep up the good work, lowest priority, and possible overkill. Indicators that need improvement are those fall into the lowest priority quadrant, namely a) Up to date information ; b) Useful information for users. Information Quality is the quality of the website content, whether the information is appropriate to users' purposes in terms of accuracy, format and relevance (Barnes and Vidgen 2002 in Tarigan, 2008) . This category is associated with the quality of website content, namely the appropriateness of information to users' purpose, regarding, for example, the accuracy, format and relevance of the information presented (Santoso \& Anwar, 2015; Suaryana, Damayanthi, \& Merkusiwati , 2016).

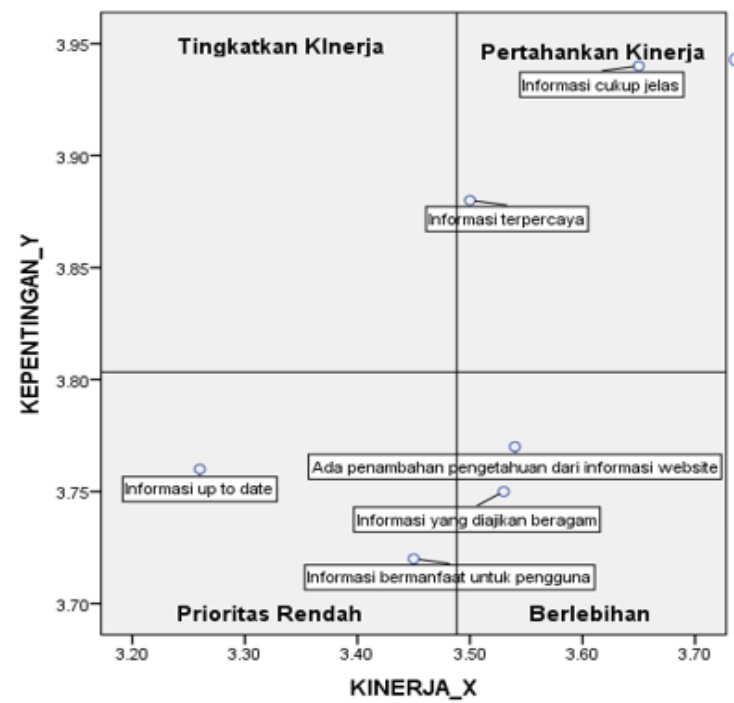

Figure 3. Information QualityVariable indicators map 
Information quality is the quality related to the amount, accuracy, and forms of information about products and services offered on a website (Nuseir, Arora, Al-Masri, \& Gharaibeh, 2010). According to Barnes \& Vidgen ( 2002) information quality is divided into several questions, namely on information that is accurate, reliable, timely, relevant, easy to understand, in accordance with users' needs and format. Based on these definitions information quality refers to website quality which include website content, information suitability and form, amount, accuracy and relevance to products or services on the website for users.

For the indicators of information is sufficiently clear, the results of descriptive statistical calculation phase in the aspect of performance shows that the indicators fall into the high category. In terms of importance, the results show that the indicators are fall into the high category. Indicators of information is sufficiently clear fall into the keep up the good work quadrant of IPA, meaning that users are satisfied with the performance provided and website managers must be able to maintain these indicators in managing the website.

For the indicators of information is reliable, the results of the descriptive statistical calculation stage in the aspect of performance show that the indicators fall into the high category. In terms of importance, the indicators also fall into the high category. Indicators of information is reliable, fall into the keep up the good work quadrant of IPA, meaning that users are satisfied with the performance provided and website managers must be able to maintain these indicators in managing the website.

For the information is up-to-date indicators, the results of the descriptive statistical calculation phase in the aspect of performance show that the indicators fall into the fairly high category. In the aspect of importance, the indicators fall into the high category. Indicators of Information is up-to-date fall into the lowest priority IPA quadrant, meaning that the indicators in this quadrant have a low level of satisfaction and at the same time users perceive their performance less important. Indicators that fall into the lowest priority quadrant are indicators that are perceived fairly appropriate and not the main priority for improvement.

Indicators for information is up-to-date are related to information delivery. This study recommends that news be uploaded regularly. According to DeLone \& McLean (2003) in Risdiyanto ( 2014), an information system can be said to have a good quality of information if the information produced is actual, if production of information needed is late, the speed of decision making will be affected, and if decision making is late, fatal consequences for users and organizations may occur.

For the indicators of information is useful for users, results of the descriptive statistical calculation phase in the aspect of performance show that the indicators fall into the fairly high category. In terms of importance, the indicators fall into the high category. The indicators of information are useful for users fall into the lowest priority of IPA quadrant, meaning that the indicators in this quadrant have a low level of satisfaction and their performance are perceived less important by users. In this case, indicators that fall into the lowest priority quadrant are perceived sufficiently appropriate and not the main priority for improvement. The indicator information is useful for users is related to the delivery of information. This study recommends that news be upload regularly. 
According to DeLone and McLean (2003) in Risdiyanto ( 2014), information systems are said to be good when relevant to user needs, if the information produced is relevant, the information will be useful. The relevance of information for each user is different from one another.

For the indicators of information presented is varied, results of the descriptive statistical calculation stage in the aspect of performance show that the indicators fall into the high category. In terms of importance, the results show that the indicators fall into the high category. Indicators of information presented is varied fall into the possibly overkill IPA quadrant, meaning that the website manager is perceived to have paid excessive attention to this variable, while users perceived the indicators fairly important.

For the indicators of additional knowledge gained from the information on the website, results of the descriptive statistical calculation phase in the aspect of performance show that the indicators fall into the high category. In terms of importance, the results the indicators also fall into the high category. Indicators of additional knowledge gained from the information on the website fall into the possible overkill IPA quadrant, meaning that website manager is perceived to have given excessive attention to this variable while users perceive the indicators fairly important.

The results of the IPA quadrant analysis of the service interaction quality variable in Figure 4 show that each variable indicator fall into the keep up the good work and low priority quadrant. Indicators that need improvement are those fell into the low priority quadrant, namely a) Speed of responses; b) Ease of communication with other organizations (links to other regional working units (SKPD)). According to Suyanto (2007) interaction means "involvement of website users as user experience with the website". Based on this definition, service interaction is involvement of website users when establishing proficiency in using the website which causes a sense of trust and empathy. From this, users feel their opinions valued.

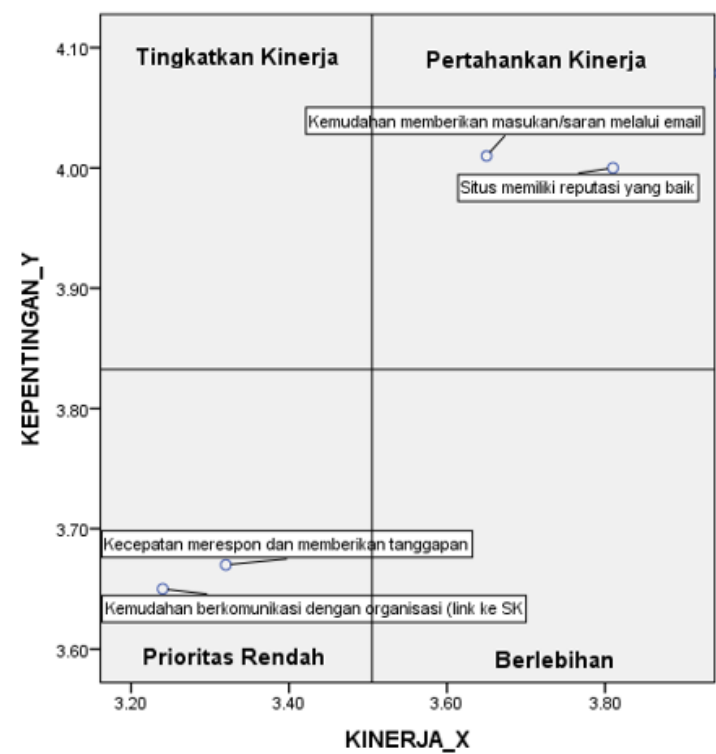

Figure 4. Service Interaction Quality variable indicators map

It is indicated that the site has a good reputation, after results of the descriptive statistical calculation phase in terms of importance show that the indicators fall into the high category. For the aspect of performance, the results show that the indicators also fall into the high category. Indicators for Website has a good reputation fall into the keep up the good work IPA quadrant, meaning that users are satisfied with the website manager performance and they should be able to maintain these indicators in managing the website. Meanwhile, results of descriptive statistics calculation phase for the indicators of easy to submit input/suggestions via email in terms of importance show that the indicators fall into the high category. In the aspect of performance, the indicators also fall into the high category. Indicators of easy to submit input/suggestions via email fall into the keep up the good work IPA quadrant, meaning users are satisfied with the website performance and website 
managers must be able to maintain these indicators in managing the website.

For indicators of ease of communication with other organizations (links to other regional working units (SKPD)), results of the descriptive statistical calculation phase in the aspect of performance, show that the indicators fall into the fairly high category. In terms of importance, the indicators fall into the high category. Indicators of ease of communication with other (links to other regional working units (SKPD)) fall into the lowest priority IPA quadrant, which reads that these indicators in have a low level of satisfaction and their performance are perceived less important by users. Indicators that fall into the lowest priority quadrant are those considered fairly appropriate and are not the main priority for improvement.

The ease of communication with other organizations (links to other regional working units (SKPD)), is related to providing tool for users to find information regarding other regional working units. This study recommends that features for communication with other regional working units be provided. According to DeLone \& McLean (2003) in Risdiyanto (2014), the ease of communication is evidence of the organization's reliability of in providing service for system users in the context of providing information needed by information system users.

For indicators of speed of response and comment, results of the descriptive statistical calculation phase in the aspect of performance show that the indicators fall into the fairly high category. From the aspect of importance, it is found out that the indicators fall into the high category. Indicators of speed of response and comment fall into the lowest priority quadrant of IPA, which reads that the indicators have a low level of satisfaction and their performance is perceived less important by users. Indicators that fall into the lowest priority quadrant are those perceived fairly appropriate and not the main priority for improvement.

The indicators of speed of response and comment are related to the services provided for website users. This study recommends that website manager provide fast and appropriate service to system users. According to DeLone and McLean (2003) in Risdiyanto (2014) the willingness to help and provide fast and appropriate service to system users can be demonstrated through (a) Information system unit's speed to provide service when needed, (b) information system unit speed of response in addressing problems experienced by information system users, (c) information of time stamp for users informing service delivery time to users, and (d) system unit's ability to provide services when needed by information system users.

\section{CONCLUSIONS}

The evaluation on the Pasuruan Regency Office of Education's website for the usability variable by descriptive analysis resulted on a conclusion that the average level of respondents' assessment on the usability variable put this variable in the high value category, while respondents' level of satisfaction at the usability variable are at less satisfaction. It is necessary to make improvement in indicators such as "type and sizes of fonts are easy to read", "background color contrasts with font colors", and "website color design is comfortable to the eyes of users" because these indicators fall into the priorities 
for improvements and low priority quadrant. Data of the analysis of the information quality variables using descriptive analysis shows that the average level of respondent's assessment of the information quality is of high value category. Meanwhile, respondents' level of satisfaction in information quality is of less satisfactory. Improvements need to be carried out for indicators such as "Information is up-to-date", "Information is useful to users" for being assessed to fall into the low priority quadrant. Data of the analysis of the service quality interaction variable using descriptive analysis shows that the level of respondents' assessment on this variable put them in the high value category. Meanwhile, respondents' level of satisfaction of on service interaction quality is of less satisfactory. Improvements needed for to indicators such as "speed of response and comment", "ease of communication with other organizations ((links to other regional working units (SKPD))", because these indicators fall into the low priority quadrant.

Based on the conclusions of the three WebQual variables, this study recommends that usability variable of website adjust its font types and sizes and adjust its background color to other website components using more attractive colors. For the information quality variable, this study suggests that Pasuruan Regency Office of Education website regularly upload information and news relating to education. On the service interaction quality variable, the study recommends improvement of service in providing quick response to any suggestions and criticisms from website users in an immediate, responsive, and friendly manner while providing convenience to communicate with other regional offices and working units (SKPD). Further studies may be conducted related to the topic of the appearance redesign to improve usability or user interface (UI) and user experience (UX) on the Regency Office of Education's website.

\section{ACKNOWLEDGEMENT}

Authors extend their appreciation to Pasuruan Regency Office of Education's stakeholder and respondents for their cooperation in providing data and information which allow the completion of the study.

\section{REFERENCES}

Barnes, S.J. (2002). An Integrative Approach To The Assessment Of E-commerce Quality. Journal of Electronic Commerce Research, 3(3), 144-127.

Brandt, D.R. (2004). An "Outside-In" Approach to Determining Customer Driven Priorities for Improvement and Innovation. Burke: White Paper Series, 5 (1).

DeLone, W.H. \& McLean, E.R. (2003). The DeLone and McLean Model of Information Systems Success: A Ten-Year Update. Journal of Management Information Systems, 19 (4), 930.

Diana. (2014). Analisis Website E-Goverment Provinsi Bengkulu Menggunakan Webqual 4.0. Jurnal Informatika, 14(2), 202-212.

Kominfo. 2018. Rancangan Peraturan Menteri Mengenai Portal dan Situs Web Badan Pemerintahan, (Online), https://www.kominfo.go.id/content/detail/9 434/siaran-pers-no-32hmkominfo032017tentang-konsultasi-publik-atas-rancanganperaturan-menteri-mengenai-portal-dansitus-web-badanpemerintahan/0/siaran pers, diakses 1 September 2018.

Latu, T.M. \& Everett, A.M. (2000). Review of Satisfaction Research and Measurement, Approaches. New Zealand: Department of Conservation.

Martilla, J.A. \& James, J.C. (1977). ImportancePerformance Analysis. Journal of Marketing, 41 (1), 77-79. 
Nasrullah. (2015). Analisis Kepuasan Penerbit Terhadap Kualitas Website ISBN Online Menggunakan Webqual dan Importance Performance Analisys. Tesis Tidak Diterbitkan, Institut Pertanian Bogor.

Nielsen, J. (2012). Usability 101: Introduction to Usability. (Online), https://www.nngroup.com/articles/usabilit y-101-introduction-to-usability/, diakses 31 Desember 2017.

Nuseir, M.T., Arora, N., Al-Masri, M.M.A., \& Gharaibeh, M. 2010. Evidence of Online Shopping: A Consumer Perspective. International Review of Business Research Papers, 6 (5), 90-106.

Recker, J. (2013). Scientific Research in Information Systems: A Beginner's Guide. London: Springer.

Risdiyanto, A. (2014). Pengaruh Kualitas Informasi, Kualitas Sistem, Dan Kualitas Layanan Terhadap Kepuasan Penffuna Pada Sistem Informasi Klinik. Skripsi Tidak Diterbitkan, Universitas Negeri Yogyakarta.
Santoso, B.S. \& Anwar, M.F., Hermawati, S. (2015). Analisis Kualitas Website Menggunakan Metode Webqual dan Importance Performance Analisys (IPA) Pada Situs Kaskus. National Conference on Information Technology and Technical Engineering (CITEE) 2015, Yogyakarta.

Suaryana, I.G.N.A., Damayanthi, I.G.A.E., \& Merkusiwati, N.K.L.A. (2016). Kualitas Dan Kepuasan Pengguna Terhadap Sistem Informasi Akademik Berbasis Web. Jurnal Ilmiah Akuntansi dan Bisnis Udayana Bali, 11 (2), 84-90.

Supranto, J. (2011). Pengukuran Tingkat Kepuasan Pelanggan Untuk Menaikkan Pangsa Pasar (2 ed.). Jakarta: Rineka Cipta.

Suyanto, A.H. (2007). Step by Step: Web Design Theory and Practices. Yogyakarta: Penerbit Andi.

Tarigan, J. 2008). User Satisfaction Using Webqual Instrument: A Research on Stock Exchange of Thailand (SET). Jurnal Akuntansi dan Keuangan, 10 (1), 34-47. 